\title{
SONGKABALA: TRADISI MENOLAK BENCANA MASYARAKAT ISLAM DESA MINASA UPA KABUPATEN MAROS SULAWESI SELATAN
}

\section{Irman}

Universitas Negeri Makassar, Sulawesi Selatan, Indonesia.

Email: irman1968041027@gmail.com

\begin{tabular}{ll}
\hline INFO ARTIKEL & ABSTRAK \\
\hline Diterima & Tradisi Songkabala merupakan tradisi masyarakat Islam Desa Minasa \\
12 Oktober 2021 & Upa, Kabupaten Maros, Provinsi Sulawesi Selatan untuk menolak bala \\
Direvisi & bencana, musibah, dan malapetaka. Dengan Meminta keselamatan \\
19 Oktober 2021 & kepada Tuhan Yang Maha Esa. Tradisi ini masih tetap dijaga karena \\
Disetujui & memiliki makna dan arti yang penting bagi masyarakat yang \\
28 November 2021 & menyelenggarakannya. Tulisan ini merupakan hasil penelitian yang \\
\hline Kata Kunci: & bertujuan selain menguraikan awal munculnya tradisi Songkabala, tradisi \\
Tradisi & Songkabala juga untuk mengungkap nilai-nilai budaya yang terkandung \\
Songkabala, & di dalamnya. Beserta fungsi yang ada pada tradisi Songkabala tersebut. \\
Fungsi, Nilai & Penelitian ini bersifat kualitatif deskriptif menggunakan teknik \\
Budaya, Tradisi & pengumpulan data berupa pengamatan dan wawancara. Hasil penelitian \\
& ini menunjukkan bahwa awal mula dilaksanakannya tradisi Songkabala \\
& sudah merupakan warisan leluhur yang sudah ada sejak dulu, yang \\
& dipercaya dapat menghindarkan bencana dan musibah. Dengan \\
& melakukan doa kepada Allah SWT, untuk meminta dijauhkan dari segala \\
& malapetaka. Pelaksanaan tradisi Songkabala secara garis besar terdiri \\
& atas tiga fungsi, yakni: mendekatkan diri kepada tuhan, bentuk \\
& pelestarian kearifan lokal, dan mencerminkan hubungan kekeluargaan \\
dalam masyarakat. Ada beberapa nilai budaya yang terkandung dalam & pelaksanaan tradisi Songkabala, yakni nilai gotong royong, nilai \\
& agama/religi, nilai musyawarah, nilai sosialisasi, nilai pengetahuan lokal, \\
dan nilai keindahan/estetika.
\end{tabular}

\section{ABSTRACT}

The Songkabala tradition is a tradition of the Islamic community of Minasa Upa Village, Maros Regency, South Sulawesi Province to reject calamities, calamities, and calamities. With salvation for God Almighty. This tradition is still maintained because it has meaning and significance for the people who hold it. This paper is the result of research that aims to describe the beginning of the emergence of the Songkabala tradition, the Songkabala tradition as well as to reveal the cultural values contained in it. Along with the functions that exist in the Songkabala tradition. This research is descriptive qualitative using data collection in the form of observations and interviews. The results of this study indicate that the initial implementation of the Songkabala tradition has been an ancestral heritage that has existed for a long time, which is believed to be able to avoid disasters and calamities. By praying to Allah SWT, to ask to be kept away from all calamities. The implementation of Songkabala

Keywords: Songkabala Tradition, broadly consists of three functions, namely: getting closer to God, a form of preserving local wisdom, and reflecting traditional relationships in society. There are several cultural values contained in the 


\begin{tabular}{|c|c|c|}
\hline $\begin{array}{l}\text { Function, } \\
\text { Cultural } \\
\text { Tradition }\end{array}$ & Value, & $\begin{array}{l}\text { implementation of the Songkabala tradition, namely the value of mutual } \\
\text { cooperation, the value of religion/religion, the value of deliberation, the } \\
\text { value of socialization, local values, and the value of beauty/aesthetics. }\end{array}$ \\
\hline
\end{tabular}

\section{Pendahuluan}

Desa Minasa Upa ialah salah satu desa di Kecamatan Bontoa, Kabupaten Maros, Provinsi Sulawesi Selatan. Dan sebagian besar dari masyarakatnya merupakan Suku Makassar yang menganu ajarant agama Islam. Islam merupakan agama mayoritas di Nusantara yang memiliki ragam pemikiran dan ritual keagaaman (Hermawan, 2019). Masing-masing daerah memiliki perbedaan antara satu dengan daerah lainnya. Perbedaan ini tidak terlepas dari tokoh agama dan corak pemahaman bagaimana yang diyakini. Desa Minasa Upa berstatus sebagai desa yang sudah pasti atau bukan sementara dan tergolong pula sebagai desa yang masyarakatnya telah mampu memanfaatkan dan mengembangkan sumber daya alam dan potensinya sesuai dengan kegiatan strategi pemerintah nasional dalam menjalankan campur tangan pemerintah untuk mempengaruhi jalannya proses pembangunan didaerah-daerah sebagai bagian dari daerah nasional supaya terjadi perkembangan kearah yang disetujui.

Berdasarkan (Pals, 1996) definisi agama adalah kepercayaan seseorang terhadap makhluk spiritual, misalnya roh, jiwa, dan hal-hal lain yang punya peran dalam kehidupan manusia. Secara umum, agama dapat didefisinikan sebagai sistem yang mengatur kepercayaan Kepada Tuhan Yang Maha Esa serta sistem kaidah yang berhubungan dengan budaya, serta pandangan dunia yang menghubungkan manusia dengan sistem kehidupan. Salah satu tradisi penting untuk sistem agama atau religi massyarakat Desa Minasa Upa ialah ritual Songkabala. Ritual ini dimaksudkan sebagai penghormatan terhadap budaya leluhur yang telah diwariskannya, sebagai bentuk permohonan agar diberi keselamatan agar terhindar dari bala bencana, musibah, maupun malapetaka. Tradsi Songkabala berarti menolak bala ataupun musibah dengan kata lain meminta keselamatan kepada Allah SWT, yang didalamnya terdapat doa yang secara bersama dilakukan masyarakat yang ikut dlalam tradisi tersebut. Yang dipimpin oleh seorang tokoh agama atau Imam Desa. Dalam ajaran Agama Islam, doa merupakan merupakan sebuah ibadah, dimana ibadah merupakan ungkapan dari lahirnya kesadaran untuk meminta pertolongan atau bantuan dari Tuhan.

Kemudian dalam melakukan doa tidak diharuskan menggunakan sebuah perantara atau media berupa sesajian yaitu makanan dan minuman. Namun, tradisi Songkabala yang dilaksanakan oleh masyarakat di Desa Minasa Upa wajib menyediakan makanan dan minuman. Dimana sajian makanan pada tradisi tersebut memiliki maknanya masingmasing sebagai pelengkap utama dalam tradisi tersebut (Sabri, 2014). Masyarakat Desa Minasa Upa sampai saat ini tetap melakukan dan mempertahankan ritual tradisi songkabala perlu pengkajian lebih mendalam mengenai apa makna dan fungsi dari ritual tersebut. Kajian ini diharapkan bisa memberikan perspektif lain dari pemahaman umum bahwa tradisi songkabala hanya sebatas ritual meminta keselamatan kepada Tuhan Yang Maha Esa, dengan cara mengirimkan doa kepada Allah SWT.

Suatu tradisi akan terus dipertahankan jika masih dianggap memiliki nilai-nilai positif atau makna-makna arti budaya yang masih tetap sangat dibutuhkan dalam menjalani kehidupan saat ini (Saputra et al., 2019). Sebaliknya, apabila hal itu dianggap sudah tidak relevan atau hal-hal yang sejenis yang saling berkaitan dengan subjek dalam konteks yang tepat atau terhubung dan terkait 
dengan situasi saat ini lagi dengan perkembangan zaman sekarang ini, maka dapat dipungkiri tradisi seperti itu cepat atau lambat akan ditinggalkan oleh masyarakat pendukungnya. Sebagaimana dengan penyelenggaraan tradisi budaya pada masyarakat lainnya, dalam penyelenggaraan tradisi Songkabala ini juga terkandung nilainilai budaya yang sangat bermanfaat dalam ikut menentukan pola pikir kehidupan masyarakat pendukungnya. Perwujudan nilainilai budaya yang dimaksud itu dapat dilihat, baik pada tahap persiapan maupun di saat berlangsungnya prosesi tradisi (Puspitasari, 2014).

Lebih lanjut dijelsakan bahwa suatu sistem nilai budaya terdiri atas pernyataan yang hidup dalam pikiran sebagian besar warga masyarakatnya, mengenai hal-hal yang wajib mereka anggap sangat bernilai atau memiliki arti penting dalam hidup. Karena itu suatu nilai budaya biasanya bertujuani sebagai pedoman untuk mengatur prilaku masyarakat itu sendiri. Semuanya berpedoman kepada sistem nilai budaya tersebut. Penelitian ini memiliki fokus permasalahan, yakni bagaimana latar belakang munculnya ritual tradisi Songkabala, bagaimana proses pelaksanaa tradisi Songkabala, Apa makna benda dan sajian makanan pada tradisi Songkabala, Fungsi yang apa yang didapatkan pada tradisi Songkabala, bagaimana pandangan Islam terhadapa tradisi Songkabala, dan nilai-nilai budaya apa saja yang terkandung dalam pelaksanaan ritual tradisi Songkabala di Desa Minasa Upa, Kecamatan Bontoa, Kabupaten Maros, Provinsi Sulawesi Selatan.

\section{Metode Penelitian}

Penelitian ini bersifat deskriptif kualitatif (Suyitno, 2018) yaitu menjelaskan tentang bagaimana latar belakang latar belakang munculnya tradisi songkabala atau tolak bala, begitupun mengenai proses pelaksanaannya. Untuk mengkaji semua ini, dikumpulkan sejumlah data yang berkaitan dengan pemahaman masyarakat tentang tradisi songkabala tersebut. Kegiatan pengumpulan data dilakukan teknik pengamatan dan wawancara oleh beberapa narasumber atau informan. Kegiatan wawancara dilakukan dengan menggunakan pertanyaann-pertanyaan. Wawancara dilakukan terutama terhadap warga masyarakat lainnya yang dianggap memahami proses pelaksanaan kegiatan tradisi Songkabala tersebut.

Dengan analisis data dipastikan dapat mengungkapkan terkait dengan rumusan masalah yang akan dibahas pada penelitian ini tentang tradisi songkabala yang masih tetap dijaga dan dirawat oleh masyarakat Desa Minasa Upa (Soendari, 2012). Dengan bertujuan untuk memberikan penjelasan mengenai fungsi tradisi Songkabala bagi masyarakat Desa Minasa Upa, makna atau arti benda dan sajian makanan pada pelaksanaan tradisi tersebut, nilai-nilai budaya yang didapat pada tradisi itu, dan pandangan masyarakat Islam mengenai tradisi tersebut.

\section{Hasil dan Pembahasan}

A. Latar Belakang Munculnya Tradisi Songkabala Atau Tolak Bala

Songkabala merupakan tradisi yang dilaksanakan guna untuk menolak bala, bencana, musiabah, maupun malapetaka yang akan datang menimpa masyarakat setempat. Songkabala dilaksanakan pada waktu tertentu dan biasanya dilaksanakan oleh masyarakat Desa Minasa Upa pada saat akan diketahu akan tiba sebuah sebuah bencana yang cukup besar. Setelah itu barulah imam Desa atau Imam Kampung mengumumkan akan dilaksanakannya tradisi songkabala tersebut. Tradisi ini juga tidak hanya dilaksanakan saat akan diketahui terjadnya sebuah bencana namun juga pada bulan lain selain waktu tersebut. Kata 
Songkabala dalam bahasa Makassar yang diketahui masyarakat Desa Minasa Upa, Kecamatan Bontoa, Kabupaten Maros, dimana memiliki makna dalam bahasa Indonesia tolak bala atau bisa juga dimaknai meminta keselamatan kepada Allah yang Maha Esa. Kabarnya, tradisi ritual Songkabala ini sudah ada sejak dari waktu ratusan tahun lalu. Dalam sejarah kehidupan masyarakat Desa Minasa Upa.

Terdapat juga beberapa pendapat tentang tradisi Songkabala yang dipandang sebagai bagian warisan manusia secara turun-temurun melalui proses belajar dari para leluhur. Pada sekarang ini, masih ada tradisi yang tetap dijaga secara turun temurun dari leluhur nenek moyang. Seperti halnyai di Desa Minasa Upa, Kecamatan Bontoa, Kabupaten Maros, Provinsi Sulawesi Selatan. Di antara tradisi yang tetap dilaksanakan oleh masyarakat Desa tersebut adalah Tradisi Songkabala. Apalagi tradisi ini memiliki nilai-niali budayai yang terkandung di dalamnya, salah satunya ialah nilai religius. Seperti dalam pelaksanaannya terdapat doa untuk meminta keselamatan kepada Allah SWT agar terhindar dari bala, bencana, musibah, maupun malapetaka. Secara tidak langsung tradisi songkabala tersebut diharapkan mampu meningkatkan keimanan warga masyarakat Desa Minasa Upa kepada Allah SWT dengan menjalankan ajaranajaran agama islam yang disampaikan oleh Allah SWT melalui utusannya yaitu Nabi Muhammad SAW. Dari beberapa penjelasan yang didapatkan ssehingga terdapat fakta bahwa tradisi Songkabala kalah suatu tradisi lokal yang lahir atau yang sudah ada sejak dari beberapa abad yang lalu.

B. Proses Pelaksanaan Tradisi Songkabala

Kebudayaan adalah suatu fenomena umum. Ritual tradisi Songkabala merupakan salah satu upacara yang dianggap penting oleh masyarakat Desa Minasa Upa, Songkabala adalah ritual orang Makassar di Desa Minasa Upa, Kecamatan Bontoa, Kabupaten Maros. Songkabala memiki arti dari bahasa melayu yaitu Songka dan Bala yang artinya menolak dan bala adalah musibah atau bencana serta malapetaka. Dari arti kata tersebut dapat disimpulkan bahwa tolak bala adalah tradisi yang bertujuan untuk agar terhindar dari malapetaka. Seperti, kejadian buruk, sial, nasib tidak baik, dan hal apa saja yang akam membawa kesengsaraan. Ritual tradisi Songkabala biasanya dilaksanakan pada malam hari setalah magrib dan biasanya dilakukannya ritual tradisi songkabala ini sebanyak tiga kali disetiap malam jum'at. Caranya dengan membakar sabut kelapa di dalam sebuah tempat yang berbentuk mangkuk atau masyarakat Desa Minasa Upa sering menyebutnya sebagai "paddupan". Setelah sabut kelapa terbakar, masukkan dupa yang bentuknya seperti teh bubuk. Jika sudah berasap, dan mengeluarkan bau harum kemudian paddupan tersebut diangkat sambil menyebarkan asap yang keluar dari tempat itu, sebab asap yang dihasilkan itu diyakini mampu menghalau bala agar terhindar dari bencana, musibah maupun malapetaka. Kemudian, tempat itu disimpan disamping makanan yang dibawa langsung dari rumah, sambil membaca doa untuk meminta/memohon keselamatan kepada Tuhan Yang Maha Esa, agar terhindar dari berbagai musibah, bencana, maupun malapetaka.

Tradisi disetiap daerah tentunya memiliki beberapa persiapan, sama halnya dengan ritual Songkabala yang dimana ritual tersebut dilaksanakan dengan berbagai macam persiapan. Ada beberapa yang harus dipahami dalam pelaksanaan tradisi Songkabala, yaitu perlengkapan atau persiapan yang akan dipakai guna 
memasuki pelaksanaan ritual tersebut. Perlengkapan ini harus ada demi terlaksananya ritual itu menurut keyakinan masyarakat setempat. Adapun persiapan dan perlengkapan yang perlu untuk di perhatikan sebelum memulai ritual Songkabala yaitu: kappara, lilin, dupa, bente, pisang manis, air minum segelas dan beberapa makanan yang diwajibkan. Ada beberapa makanan yang wajib disediakan dalam ritual songkabala ini. Antara lain: ka'do masingkulu, umbaumba, lappa-lappa, dan apang.

Semua makanan tersebut memiliki maknanya masing-masing. Seperti, ka'do masingkulu memiliki arti "massingkulu" artinya menyiku. Ka'do massingkulu akan menyiku segala bencana atau bala yang akan terjadi dan menahan bencana tidak datang, umba-umba memiliki arti sebuah simbol datangnya kebahagian, lappa-lappa memiliki arti lappa-lappa. Menurut masyarakat Desa Minasa Upa, yaitu untuk melipat-lipat segala bencana yang akan terjadi dan akan menjauhkan bala bencana yang akan terjadi, dan apang memiliki arti melambangkan harapan agar kehidupan tenteram dan aman tanpa adanya gangguan yang akan memberikan kesialan seperti bencana dan musibah. Itulah beberapa arti dan makna dari makanan tersebut. Kemudian apabila sajian makanan yang diwajibkan sudah selesai dibuat maka makanan tersebut diletakkan di wadah yang lumayan besar yang berbentuk bulat. Wadah tersebut terbuat dari bahan besi, masyarakat Desa Minasa Upa menyebutnya dengan kappara. Berbagai sajian hidangan disusun dengan rapi lalu makanan-makanan yang sudah ditata kemudian dibawa ke masjid sebelum magrib. Di sanalah, hidangan makananmakanan masyarakat dikumpulkan menjadi satu. Sudah sholat magrib, Jika sudah tidak ada lagi yang ditunggu dan semua syarat sudah ada atau lengkap maka ritual akan dimulai. Doa dipanjatkan oleh Imam Desa dan tokoh masyarakat lainnya untuk meminta keselamatan guna terhindar dari segala bala yang mengancam.

C. Makna Atau Arti Benda Dan Sajian Makanan Pada Ritual Tradisi Songkabala

Makna suatu benda dan sajian makanan pada sebuah tradisi tentunya sudah ada dalam setiap budaya, secara umum makna adalah sebuah arti. Dapat dikatakan hampir mirip dengan filosofi. Sehingga dapat dikatakan bahwa makna benda dan sajian makanan pada sebuah tradisi memiliki arti yang berbeda-berbeda menurut kepercayaan masyarakat setempat. Salah satu contohnya tradisi Songkabala di Desa Minasa Upa dimana dalam pelaksanaannya terdapat benda dan sajian makanan yang memiliki makna atau arti. Menurut beberapa masyarakat mengenai makna dan arti benda dan sajian makanan pada tradisi songkabala yaitu:

1. Ka'do' massingkulu

Ka'do massingkulu merupakan salah satu jenis makanan khas Makassar yang kita sering temui dengan rasa yang sangat enak, terbuat dari beras dan berbentuk seperti segitiga sama sisi yang dimakan bersama kelapa parut yang digoreng. Atau yang dikenal sebagai "bundubundu" pada masyarakat setempat. Siapa sangka makanan yang enak ini memiliki arti yang baik bagi masyarakat Desa Minasa Upa, pada sebuah tradisi Songkabala. Dimana ka'do artinya makan dan masingkulu ialah menyiku. Jadi makna makanan ka'do massingkulu bertujuan untuk menyiku segala musibah yang terjadi serta menahannya untuk tidak terjadinya bencana yang datang dari mana saja.

2. Umba-umba 
Umba-umba merupakan salah satu jenis kue dan makanan khas Makasaar yang sering ada pada sebuah tradisi, umba-umba ini juga dikenal sebagai onde-onde. Maksud dari makanan ini adalah memiliki arti simbol kebahagiaan tanpa adanya gangguan hal-hal yang membuat menyengsarakan masyarakat setempat.

3. Lappa-lappa

Lappa-lappa juga merupakan makanan dari Makassar, makna dari makanan lappa-lappa, sudah dijelaskan sebelumnya bahwa arti dari kata lappalappa adalah melipat, makna serta arti makanan lappa-lappa menurut masyarakat setempat ialah untuk melipat segala bencana yang akan terjadi dan bertujuan untuk menghadangnya bala bencana yang akan datang tersebut dan menjauhkannya.

4. Apang

Kue apang merupakan salah satu jenis makanan khas BugisMakassar yang memiliki aroma yang sangat wangi, rasanya yang manis karena penggunaan gula merah sebagai bahan utama selain tepung beras. Disertai rasa yang enak ditambah dengan parutan kelapa untuk menambah kenikmatannya. Kue tradisional khas suku Bugis-Makassar ini memiliki bentuk beragam, ada yang bentuknya segitiga, ada juga yang bentuknya kotak. Kue apang ini tentu harus ada disetiap tradisi Songkabala karena memiliki arti makna mendalam. Apang melambangkan harapan agar kehidupan tenteram dan aman.

5. Lilin

Lilin secara umum memiliki arti sebagai sumber penerangan yang mempunyai sumbu yang diselimuti oleh bahan bahan bakar padat yang sangat mudah untuk terbakar. Lilin yang kita ketahui juga memiliki berbagai hal yang berbeda. Bagi sebagian orang, itu melambangkan harapan dan bimbingan. Bagi orang lain, mereka mewakili kehidupan, kebijaksanaan, dan kepemimpinan. Lilin juga kerap menjadi simbol pengorbanan.

6. Dupa

Dupa adalah bahan yang harus ada dalam tradisi Songkabala, dimana bertujuan dapat memberikan bau harum pada acara pelaksanaan tradisi Songkabala dengan cara menaburkan dupa diatas bara api yang diletakkan didalam paddupan atau tempat bara untuk menabur dupa atau tempat dupa.

7. Bente

Bente ialah padi yang digoreng menggunakan wajan. Bente juga menjadi poin utama yang harus ada dalam pelaksanaan tradisi ritual Songkabala. Bente bertujuan meringankan bala yang akan datang agar dapat dijauhkan.

8. Pisang manis

Pisang manis atau yang disebut juga masyarakat setempat sebagai unti te'ne dalam bahasa makassarnya. merupakan yang harus disediakan karena dipercaya oleh masyarakat bahwa keistimewaan dari buah pisang tersebut.

9. Air segelas

Segelas air ialah syarat yang wajib ada dalam pelaksanaan ritual tradisi Songkabala. Air segelas dipercayai serta diyakini masyarakat setempat sebagai air minum dari makanan yang telah disediakan. Makna dari air yang kita ketahui ialah sebagai ketenangan, dan selau mengalir ke tempat lebih rendah, mengajarkan kita selalu rendah hati.

D. Fungsi Tradisi Songkabala 
Seperti yang kita ketahui bahwa setiap tradisi tentunya mempunyai fungsi ataupun tujuan mengapa kita melakukannya, dimana tradisi adalah suatu tindakan yang di dasarkan pada spiritual yang dapat menyampaikan agama terhadap masyarakat melalui budayanya yang mampu memberikan arti penting dan tujuan hidup seseorang. Spiritualitas juga bisa dikatakan sebagai seseorang yang mempercayai tuhan, contohnya seperti seseorang yang beragama Islam atau Muslim yang mengimani Allah SWT sebagai pencipta serta pengatur semua yang ada pada muka bumi ini atau dialam semesta ini. sehingga mampu dikatakan bahwa dengan adanya unsur spiritual di tradisi yang di dalamnya ada kepercayaan serta perasaan sehingga tradisi selalu dimiliki pada setiap daerah. dengan munculnya tradisi seseorang dapat melestarikan dan mengenang warisan dari leluhur sebagai akibatnya generasi berikutnya bisa meneruskan tradisi yang sudah ada tersebut dan tidak akan hilang begitu saja. Terkait dengan fungsi tradisi Songkabala, maka berikut ini ada beberapa penjelasan yang saya temui mengenai fungsi tradisi tersebut bagi masyarakat Desa Minasa Upa adalah sebagai berikut.

1. Bisa Mendekatkan Diri Kepada Tuhan

Kata Songkabala dalam bahasa Makassar yang dipahami oleh masyarakat Islam Desa Minasa Upa mengandung makna dalam bahasa Indonesia tolak bala yang artinya menolak bencana, musibah, atau malapetaka. Yang bisa juga diartikan sebagai meminta doa permohonan atau keselamatan kepada Tuhan Yang Maha Esa. Doa yang dimaksud merupakan doa untuk menjauhkan dari segala bencana, musibah ataupun malapetaka yang akan menimpa, menurut keyakinan masyarakat Desa Minasa Upa. Dikatakan bahwa tradisi Songkabala itu tidak bertentangan dengan ajaran Islam, dikarenakan dalam setiap kegiatannya ataupun pelaksanaannya tersebut tidak didapatkan hal-hal yang tidak sesuai dengan ajaran Islam sebab masyarakat hanya memanjatkan doa kepada yang maha kuasa agar terhindar atau menjauhkan dari segala bencana, malapetaka, atau bahaya yang akan menimpa masyarakat.

Dengan kata lain tradisi Songkabala ini, pelaksanaan yang paling utama hanyalah mengirim doa kepada Allah SWT agar bala atau bencana yang akan menimpa masyarakat itu dijauhkan. Doa merupakan permintaan atau permohonan, serta penyerahan diri kepada Allah SWT dalam memohon keinginan dan meminta dihindarkan dari hal yang tidak disukai atau dibenci. Manfaat doa buat umat Muslim, berdoa adalah kegiatan sederhana yang umum dilakukan. Selain bertujuan untuk sebagai ibadah utama kepada Allah SWT, berdoa juga dilakukan sebagai cara memohon agar apa yang diinginkan dapat dan bisa terkabul. Bisa dikatakan, berdoa dapat memudahkan kita dari segala macam urusan kehidupan, karena doa sangat diharuskan dan dianjurkan untuk dilakukan oleh Nabi Muhammad SAW. Dengan adanya doa dalam pelaksanaan tradisi Songkabala, sehingga kita bisa lebih mendekatkan diri kepada Tuhan.

\section{Bentuk Pelestarian Kearifan Lokal}

Seperti yang kita ketahui bahwa kearifan lokal adalah suatu bentuk kebijaksanaan yang didasari oleh nilainilai kebaikan yang dianggap, serta diterapkan dan senantiasa dijaga setiap pada kurun waktu yang relatif lama atau dengan secara turun-temurun oleh sekelompok orang dalam lingkungan atau daerah eksklusif yang menjadi tempat tinggal mereka. salah contoh terwujudnya bentuk kearifan lokal masyarakat Desa Minasa Upa melalui tradisi Songkabala adalah menggunakan harapan besar buat tetap menjalankan adat tradisi yang sudah lama diikuti secara turun temurun. Kearifan lokal tumbuh 
serta menjadi bagian dari kebudayaan masyarakat Desa Minasa Upa, di mana beberapa hal akan berperan penting pada perkembangannya, di antaranya: Bahasa, agama, kesenian, tingkat pendidikan masyarakat, perkembangan teknologi serta yang lainnya. sehingga dapat dikatakan bahwa bentuk pelestarian kearifan lokal pada tradisi Songkabala di Desa Minasa Upa merupakan kearifan lokal tradisional atau kearifan lokal lama. yang mana kearifan lokal di sini adalah kearifan lokal yang sudah dijalankan secara turun temurun pada waktu yang sangat panjang.

Dari penjelasan di atas dapat dikatakan bahwa kearifan lokal merupakan sesuatu hal yang sudah melekat di masyarakat dan sudah menjadi karakteristik khas pada wilayah tertentu secara turun-temurun dan sudah diakui oleh masyarakat luas. Selain itu, kearifan lokal dikembangkan selama beberapa generasi serta dapat tertanam di dalam cara hidup masyarakat lokal yang memiliki sangkut paut sebagai sarana untuk mempertahankan hidup. Jadi kesimpulannya ialah kearifan lokal merupakan semua bentuk pengetahuan, keyakinan, pemahaman, atau wawasan serta tata cara kebiasaan atau tata cara yang menuntun perilaku manusia pada kehidupan komunitas. Ekologis Kearifan lokal ini juga tak bisa dilepaskan dari kebudayaan warga yang mendukung. aturan adat adalah aturan norma, tetapi norma yang mempunyai dampak aturan pemuka adat menjadi pemimpin yang sangat disegani dan besar pengaruhnya dalam lingkungan masyarakat adat untuk menjaga keutuhan hidup sejahtera.

3. Mencerminkan Hubungan Kekeluargaan Dalam Masyarakat

Masyarakat dibangun oleh adatistiadat ataupun kebiasaan norma berupa sebuah tradisi yang sudah membudaya, menjadi hasil dari proses berpikir yang kreatif serta produktif. Aturan adat lebih menjadi hal atau pokok yang sebagai dasar, pegangan, acuan, atau petunjuk buat menentukan atau melaksanakan sesuatu, untuk terjaminnya serta terpeliharanya etika kesopanan, tata tertib, sikap dan nilai adat pada kehidupan masyarakat. seperti yang kita ketahui bahwa pandangan Islam asal segi hubungan masyarakat atau sesuai nilai ukhuwah yaitu adanya persaudaraan antara sesama umat Islam, dimana pada tradisi Songkabala yaitu Islam menganjurkan untuk saling menjaga tali silaturahmi. Nilai ukhuwah artinya nilai yang sangat utama bagi umat Muslim untuk mempererat tali silaturahmi antara masyarakat buat terciptanya suatu persaudaraan, kedamaian, kesamaan serta kedamaian dalam menjalankan kehidupan secara bersama-sama dalam menciptakan kebudayaan dan peradaban yang lebih maju lagi kedepannya.

Gotong royong memiliki makna bekerja sama, sangat jelas dipikirkan dalam tradisi Songkabala ini karena pada pelaksanaannya terlihat adanya sikap saling membantu, saling memberikan bantuan guna terlaksananya sebuah tradisi yang dimana sudah menjadi tujuan bersama sebagai wujud manusia makhluk sosial. Songkabala sebagai tradisi mencerminkan suatu proses hidup yang berkelanjutan pada kehidupan masyarakat yang sudah tidak bisa dipisahkan oleh budaya yang menyatukannya, sebab budaya mampu sebagai pemersatu bagi warga di satu wilayah eksklusif sebab menganggap diri mereka sama yaitu satu budaya. warga Desa Minasa Upa adalah suku Makassar, dengan kata lain masyarakatnya sangat rata dimana masyarakatnya dengan ciri-ciri ras, etnis, agama serta budaya yang sama dan lebih mengikuti gaya hidup dengan budaya yang sama, pada arti lain.

Darah suku Makassar yang sangat dikenal jelas mempertahankan kebudayaannya maupun kearifan lokal 
yang dijalankan oleh setiap masyarakatnya memberikan dampak secara individu terhadap kekeluargaan lada masyarakatnya. Songkabala merupakan salah satu tradisi masyarakat Desa Minasa Upa yang masih ada hingga kini. Tradisi tersebut dilakukan oleh setiap orang yang meyakininya dan tercipta kerukunan prilaku gotong royong sesama masyarakat. Islam mengajarkan untuk saling menghargai dan menghormati satu dengan yang lainnya begitulah dengan warga Desa Minasa Upa yang tetap melestarikan tradisi kebudayaan ini, pula mempunyai tujuan buat menghargai tradisi nenek moyang atau leluhur mereka. Kehidupan sosial warga Desa Minasa Upa terutama yang tetap melestarikan tradisi Songkabala sangat berpengaruh di dalam masyarakat dimana mereka hidup tentram, saling menghargai, senang bergotong royong, menyayangi dan menghargai kebudayaannya. Tradisi yang tetap dipertahankan masyarakat Desa Minasa Upa telah membuat kepribadian dan watak warganyat yang bertanggung jawab, menghargai disparitas, peka terhadap perubahan lingkungan di sekitarnya, mempunyai jiwa kepedulian sosial yang tinggi dalam menolong sesama. Hal ini dapat kita lihat melalui hubungan kekeluargaan yang terdapat pada masyarakat Desa Minasa Upa tersebut.

E. Nilai-nilai Budaya yang Terkandung dalam Pelaksanaan Tradisi Songkabala

Nilai dalam pembahasan ini tidak memiliki kaitannya dengan angka atau harga. Nilai dalam arti kali ini ialah sebuah sikap, pendirian atau cara yang diberi nilai tinggi oleh seseorang, sebuah suku, kelompok atau bangsa. Keyakinan dan Nilai kemudian menjadi dasar atau alasan untuk menghasilkan sebuah budaya dan untuk bersikap serta berperilaku seperti yang selalu mereka perlihatkan.
Relevan dengan hal tersebut, Achmad. S. Ruky (Pada Budaya, Lintas Budaya dan Lingkungan, 2017) dan (Kaukab, 2017) menjelaskan bahwa nilainilai budaya atau kultural adalah nilai-nilai yang disetujui oleh semua anggota masyarakat, suku atau bangsa. Sedangkan yang dimaksud dengan sistem nilai kultural pada dasarnya adalah urutan dari semua nilai yang dipegang oleh sebuah kelompok, suku atau bangsa berdasarkan derajat penting nilai-nilai tersebut. Setelah menelaah lebih mendalam tentang pelaksanaan tradisi songkabala, mulai dari tahap persiapan hingga tahap pelaksanaan diketahui tentang nilai-nilai budaya yang terkandung di dalamnya. Untuk lebih jelasnya uraian mengenai hal yang terdapat beberapa nilai yang sangat penting yang tercermin dalam kegiatan tradisi Songkabala tersebut yaitu dapat dilihat sebagai berikut :

1. Nilai gotong royong

Secara umum yang kita ketahui perihal gotong royong adalah saling kerja sama dalam mencapai suatu tujuan demi kepentingan bersama. Apalagi, orang Indonesia tentunya telah tidak asing lagi dengan istilah ini. Gotong royong sudah menjadi budaya masyarakat di Indonesia sejak berabadabad yang lalu. Budaya gotong royong melalui sebuah tradisi di Indonesia dapat dibuktikan dalam berbagai macam bentuk serta istilah yang tidak selaras sesuai dengan daerah masingmasing. contohnya tradisi Songkabala masyarakat Desa Minasa Upa dalam melakukan persiapannya diharapkan nilai gotong royong pada hal pelaksanaannya. berangkat dari hal itu, pemahaman nilai-nilai kegotong royongan tergeser atau berubah bisa saja terjadi sebab kehidupan bermasyarakat bergeser sesuai dengan perkembangan teknologi. masyarakat 
sebagaimana

disampaikan

(Koentjaraningrat, 1985).

Gotong royong sebagaimana

dijelaskan di atas, memiliki kesamaan pula dalam penyelenggaraan ritual tradisi Songkabala, khususnya yang berhubungandengan persiapan pelaksanaannya. Di tahap persiapan tersebut, terwujudny nilai kegotongroyongan sangat jelas terlihat, mulai dari para masyarakat Desa Minasa Upa secara bersama melakukan aktivitas pembersihan lokasi yang akan dijadikan tempat penyelenggaraan ritual tradisi songkabala tersebut. Begitu pula ketika membuat makanan yang disyaratkan dibawa ke lokasi semua bekerja demi suksesnya penyelenggaraan acara. Dalam kategori semacam ini sudah jelas memiliki pengaruh yang baik dalam tradisi Songkabala ini sebab dalam pelaksanaannya terlihat adanya sikap saling tolong-menolong, saling memberikan bantuan demi terlaksananya sebuah tradisi yang menjadi tujuan bersama sebagai wujud nilai dasar yang dimiliki manusia sebagai makhluk sosial yang tidak biasa hidup sendiri melainkan membutuhkan pertolongan orang lain. Oleh sebab itu di dalam kehidupan masyarakat diperlukan adanya kerja sama dan sikap gotong royong guna dalam menyelesaikan segala permasalahan dan persoalan yang terjadi.

2. Nilai agama/religi

Tradisi songkabala merupakan salah satu tradisi yang bisa membuat kita bisa sangat erat dengan Tuhan. Perwujudan nilai agama atau religi dalam penyelenggaraan ritual adat tersebut, dapat dilihat pada beberapa hal, seperti pada saat acara yang sudah berlangsung di malam hari. Dalam acara tersebut, seorang ulama atau yang disebut sebagai iman kampung melakukan pembacaan ayat-ayat suci Alquran dan doa-doa keselamatan dan kesejahteraan untuk seluruh lapisan masyarakat Desa Minasa Upa. Saat prosesi pembacaan ayat suci Alquran dan doa berlangsung, seluruh masyarakat yang hadir mengikutinya dengan penuh hikmat hingga acara berakhir. Sikap, tindakan, dan ucapan yang ditunjukkan para ulama dan masyarakat lainnya dalam hal ini, mengandung makna bahwa nilai agama/religius memberi bimbingan dan arahan untuk mengajak manusia agar senantiasa menyerahkan diri kepada Tuhan Yang Maha Kuasa agar keselamatan dan kesejahteraan yang diinginkan tercapai.

Demikian pula sikap yang ditunjukkan oleh masyarakat Desa Minasa Upa yang menghadiri ritual tradisi tersebut, membuktikan betapa besar rasa cinta dan didasari oleh akidah dalam bentuk persahabatan dan persaudaraan bagaikan satu tiang yang kokoh, sebagai suatu wujud persaudaraan karena Allah SWT. Seperti yang kita ketahui bahwa nilai agama atau religi dalam budaya merupakan sekumpulan nilai-nilai agama yang melandasi perilaku, tradisi, dan kebiasaan-kebiasaan yang dilakukan secara turun temurun oleh masyarakat di setiap daerah. Nilai agama atau religi dalam konteks ini berarti pembudayaan nilai-nilai agama Islam dalam kehidupan di masyarakat Desa Minasa Upa yang bertujuan untuk menanamkan nilai-nilai agama Islam yang diperoleh dalam tradisi tersebut.

Ada di antaranya adalah tradisi yang bersifat religi atau keagamaan dan berkembang baik di daerah. Selain 
untuk memberikan gambaran jelas mengenait ukhuwah, tradisi ini pula bisa dikatakan sebagai syiar Islam. Kebudayaan yang diciptakan oleh manusia itu sendiri merupakan bukti bahwa manusia tersebut berpikir, membuktikan bahwa mereka bisa terus membentuk sebuah peradaban yang baru guna mencapai nilai tertinggi. Warganya dengan kemampuan menjadiakn kebudayaan dan mengembangkan kebudayaan tersebut harus sejalan dengan hukum adat yang berlaku misalnya kebudayaan berupa tradisi. Tradisi adalah kebudayaan tradisional masyarakat lokal yang masih ada ditemukan dibeberapa tempat serta masih dipertahankan sampai sekarang.

Tradisi Songkabala contohnya, masih tetap dilestarikan oleh masyarakat Desa Minasa Upa Kabupaten Maros. Sebab memiliki nilai serta mempunyai makna yang sangat mendalam bagi warga setempat yang masih menyakininya. Seperti halnya dengan kebiasaan yang lahir dari kegiatan manusia sehari-hari membentuk kebudayaan yang harus sesuai dengan ajaran agama Islam serta hukum adat yang berlaku dalam masyarakat. Pandangan Islam dari segi pelaksanaan tradisi Songkabala seperti memanjatkan doa memohon keselamatan tidak bertentangan dengan ajaran Islam, sebagai akibatnya sangat jelas atau tujuan doa tersebut dipanjatkan kepada Allah SWT.

3. Nilai musyawarah

Kata musyawarah sudah tidak asing lagi bagi masyarakat Indonesia dimana, musyawarah sebagai upaya bersama untuk menyelesaikan permasalahan dan persoalan di dalam masyarakat. Apalagi dalam Desa Minasa Upa merupakan masyarakat
Islam dimana musyawarah memiliki posisi mendalam dalam kehidupan masyarakat Islam. Bukan sekadar sistem politik pemerintahan, tapi juga merupakan karakter dasar seluruh masyarakat. Seluruh persoalan didasarkan atas musyawarah, lalu dari masyarakat, prinsip ini merembes ke pemerintahan bahkan menjadi sesuatu yang sangat mendasar dalam kehidupan umat manusia, yang dalam setiap saat perkembangan umat manusia, musyawarah akan menjadi bagian yang tidak terpisahkan di tengah perkembangan kehidupan umat manusia. Dalam kehidupan sosial, baik dalam lingkup keluarga, masyarakat ataupun bangsa, musyawarah mutlak diperlukan karena merupakan salah satu sarana yang dapat dimanfaatkan untuk mencegah atau mengatasi konflik.

Bisa atau dapat dikatakan bahwa kata musyawarah pada dasarnya hanya digunakan untuk hal-hal yang baik, sejalan dengan makna dasarnya. Musyawarah adalah cara merumuskan sesuatu hal berdasarkan kehendak, keputusan dan kesepakatan orang banyak. Akan tetapi suatu keputusan diutamakan kebulatan pendapat yang berdasarkan atas kata sepakat atau mufakat. Dimana yang kita ketahui memiliki arti kesepakatan untuk melaksanakan hasil musyawarah. Salah satu ritual adat yang dalam penyelenggaraannya atau pelaksanaannya masih menonjolkan dan mengharuskan nilai musyawarah adalah ritual tradisi Songkabala.

Pada pelaksanaan tradisi songkabala tersebut, segala halnya diputuskan dengan cara musyawarah sesama masyarakat atau tokoh agama. sebagai contoh misalnya, keputusan buat menentukan waktu dan tanggal 
dilaksanakannya tradisi Songkabala tersebut. dalam pengambilan kesepakatan itu, seluruh masyarakat menerima dan memahami hasilnyait tanpa menyebabkan perpecahan serta perselisihan. Artinya ialah salah satu kearifan lokal yang berbentuk musyawarah yang masih berlaku di masyarakat Desa Minasa Upa serta bisa digunakan menjadi cara buat mencegah perseteruan.

4. Nilai sosialisasi

Seperti yang diketahui bersama bahwa sosialisasi dimaknai menjadi suatu proses dalam berhubungan dengan individu lainnya dan sudah menjadi sebagi penanaman nilai, kebiasaan, serta aturan pada bertingkah laku di masyarakat dari satu generasi ke generasi lainnya dengan peran dan status sosial masing-masing pada kelompok masyarakat. Melalui proses sosialisasi maka seorang bisa memahami serta menjalankan hak dan kewajibannya masing-masing sesuai bagaimana peran status masing-masing sesuai dengan budayanya sendiri pada daerahnya. Dalam masalah ini, setiap individu mengkaji dan membuatkan pola-pola perilaku sosial dalam proses kedewasaan diri. dengan kata lain, anggota keluarga, guru, pemuka agama, serta elemen rakyat lainnya, mempunyai kiprah dalam proses pengenalan setiap individu.

Pada pelaksanaan ritual tradisi Songkabala, proses sosialisasi dapat dan bisa terjadi kapan serta dimana saja itu, terutama pada anak-anak dan remaja sebagai generasi muda penerus bangsa. Walaupun pada kenyataannya atau faktanya mereka tidak terlalu banyak berperan pada pelaksanaan ritual, misalnya membantu mengerjakan berbagai aktivitas demi suksesnya pelaksanaan ritual tradisi, tapi setidaknya mereka pula belajar tentang budaya serta tradisi tersebut yang pada akhirnya kelak bisa menggantikan generasi sebelumnya. Generasi muda dapat mengambil pesan tersirat serta pelajaran, bahwa pelaksanaan ritual tradisi Songkabala dapat membangun kerukunan, keakraban, serta harmonisasi pada antara para masyarakat Desa Minasa Upa yang terlibat. Selain itu mereka pula belajar, bahwa di dalam aktivitas ritual, terjadi sifat kebersamaan serta solidaritas yang tinggi, bukan hanya sesama warga setempat, melainkan pula dari luar tanpa membeda-bedakan status sosialnya.

5. Nilai pengetahuan lokal

Pengetahuan umum atau tradisional yang kita ketahui adalah kepercayaan suatu daerah setempat dalam tatanan lingkungan spesifik lokasi. Pengetahuan lokal dikembangkan secara evolutif dimana suatu perubahan yang terjadi secara berangsur angsur atau bertahap sehingga evolutif identik dengan suatu perubahan yang terjadi membutuhkan waktu yang lama, proses pengaplikasaian, penyesuaian serta regenerasi terus menerus sepanjang masa keberadaan masyarakat tradisional itu. Namun nilai pengetahuan lokal yang dimaksudkan di sini, ialah pengetahuan tentang waktu. Sampai saat ini masyarakat Desa Minasa Upa, khususnya yang masih memegang teguh nilai-nilai tradisional masih tetap mempertahankan warisan budaya nenek moyang mereka mengenai konsepsi tentang waktu yang dipercaya baik dan dianggap buruk untuk memulai suatu pekerjaan.

Misalnya, pada saat pelaksanaan ritual tradisi Songkabala tersebut 
memerlukan waktu yang khusus tidak boleh sembarangan dalam mengambil hari, bagi masyarakat Desa Minasa Upa hari yang tepat untuk melaksanakan ritual ini adalah hari Senin, kamis, dan jum'at dan dilakukan pada malam hari setelah magrib yang dipercaya pada saat itu banyak jin kafir yang berkeliaran dan akan membawa malapetaka atau musibah. Sehingga pada saat itu masyarakat berdoa bersama-sama meminta keselamatan kepada Allah SWT agar terhindar dari bencana atau musibah tersebut yang dipimpin langsung oleh tokoh agama atau istilah yang digunakan pada masyarakat tersebut adalah Imam Kampung atau Imam Desa.

6. Nilai keindahan/estetika

Menjadi manusia yang mengaku berbudaya telah sempurna dalam hal yang namanya nilai seni. Seni adalah salah satu nilai terpenting dalam sebuah kebudayaan. Seni bisa kita lukiskan menjadi sebuah estetika/keindahan yang sudah erat kaitannya dengan budaya yang dapat memberikan manfaat nilai rekreatif bagi pemiliknya dan pengamat kebudayaan. estetika ialah suatu bentuk nilai, seperti halnya nilai pada prilaku manusia, nilai pendidikan, dan sebagainya. Nilai yang tercakup dalam pengertian keindahan dianggap nilai estetis. keindahan bagi manusia merupakan sesuatu yang sangat penting karena manusia itu mempunyai perasaan yang halus, lembut, dan menghargai kualitas. Tingginya cita rasa artistik seorang pada meresapkan karya-karya yang indah, pada gilirannya akan memberikan dampak positif terhadap perilaku emosi dan perilaku moralnya (Marwadi dan Hidayati, 2004:142).
Sedangkan arti atau definisi keindahan/estetika yang dikemukakan oleh Bruce Allsopp (1977) dalam mengartikan mata estetika ialah sebuah ilmu pengetahuan, Allsopp juga mengungkapkan bahwa estetika adalah suatu aktivitas edukasi atau pembelajaran tentang proses serta aturan perihal penciptaan sebuah karya yang nantinya akan menyebabkan perasaan nyaman bagi yang melihat dan merasakannya. dengan istilah lain keindahan (estetika) sangat dibutuhkan pada sebuah kebudayaan, seperti yang dikemukakan sang seorang Antropolg E.B. Tylor mengatakan bahwa kebudayaan adalah kompleks yang mencakup pengetahuan, agama, kesenian, moral, hukum, tata cara istiadat serta lain kemampuankemampuan serta norma-kebiasaan yang didapat oleh manusia sebagai anggota masyarakat.

Sehingga dapat dikatakan bahwa estetika dapat dikatakan sebagai teori keindahan atau seni. estetika berkaitan dengan nilai indah. Nilai estetika berarti nilai wacana estetika. Dalam hal lainnya, terdapat juga yang melihatnya sebagai suatu bagian penting filsafat. berangkat dari sudut pandang filsafat, pengertian estetika ialah cabang filsafat yang membahas estetika itu sendiri. Tidam hanya keindahan dalam hal seni, melainkan estetika secara umum, termasuk keindahan alam semesta itu sendiri. istilah keindahan tak jarang kali dipergunakan bersamaan dengan ungkapan atau evaluasi perihal suatu karya seni. namun, secara umum yang kita ketahui perihal estetika yaitu, keindahan ialah nilai-nilai keindahan. estetika sering muncul menjadi bentuk pujian atau observasi wacana suatu objek. Selain itu, kata estetika selalu dikaitkan dengan yang namanya seni. 
Sebab seperti yang kita ketahui bahwa, dalam karya seni seseorng pastinya memiliki nilai-nilai keindahan di dalamnya. namun ternyata, pengertian keindahan tidak sebatas pada keindahan karya seni. Pada pelaksanaan ritual tradisi Songkabala, ada beberapa hal yang mengandung unsur keindahan, seperti jenis makanan yang dibuat atau disiapkan oleh masyarakat.

F. Pandangan Islam Terhadap Tradisi Songkabala

Bertemunya Islam dan kebudayaan akan memberikan wajah Islam yang dikenal sebagai Rahmatanlil'alamin, jaran Islam yang luas dan terbuka terhadap kebudayaan yang majemuk yang hidup di tengah masyarakat daerah tidak bisa dipungkiri ajaran agama akan diterima dengan mudah. Namun apabila ajaran Islam dikembangkan dengan tidak terbuka terhadap budaya yang hidup dimasyarakat, maka Islam akan sulit hidup di Indonesia (Abdullah, 1974). Islam sudah membentuk agama yang mempunyaii ajaran yang universal yang mengandung nilai-nilai budaya dan mengatur segala kegiatan manusia baik menyangkut hubungan manusia dengan manusia, manusia dengan mahluk hidup lain misalnya binatang, tanaman, dan hubungan manusia dengan lingkungan atau alam sekitarnya, serta hubungan manusia dengan penciptanya (Jeumpa, 2018). agama dan kebudayaan yang telah dibawa Rasulullah Muhammad SAW pada umat manusia ialah sudah menjadi satu kesatuan yang tidak bisa lagi kita pisahkan.

Kebudayaan menemukan perhatian yang fokus pada Islam. Dikarenakan telah mempunyai peranan yang penting untuk membumikan ajaran utama sesuai dengan kondisi serta kebutuhan hidup manusia (Mansoer,2004: 163). masyarakat dengan kemampuan dalam menciptakan kebudayaan serta menyebarkan kebudayaan tersebut wajib sama dengan adat norma yang ada pada masyarakat seperti halnya kebudayaan berupa tradisi. Tradisi ialah kebudayaan tradisional yang masih banyak ditemukan disetiap masyarakat daerah dan sampai kini tetap dipertahankan. Tradisi songkabala contohnya, masih tetap dilestarikan oleh masyarkat Desa minasa Upa, di kecamatan Bontoa, Kabupaten Maros karena memiliki nilai dan mempunyai makna yang sangat penting bagi warga setempat.

Agama tidak hanya bisa ditinjau sebagai "akibat" kebudayaan. Pembicaraan tentang yang namanya agama Islam pada kebudayaan selalu menjadi sesuatu yang unik. Secara umum konsep Islam berangkat oleh dua objek hubungan yakni dengan Allah SWT dan hubungan dengan sesama manusia. Jadi Islam mempunyai dua aspek, yakni segi kepercayaan dan segi kebudayaan. dengan demikian, terdapat kepercayaan Islam maupun ada kebudayaan Islam. pada pandangan tentang hal tersebut, antara keduanya dapat dibedakan, namun dalam pandangan Islam sendiri tidak mungkin dipisahkan. Pada teori masuknya Islam di wilayah Nusantara yang sudah kita pelajari tentunya. Islam datang tidak untuk menghapus atau mengubah kebiasaan budaya masyarakat yang telah terdapat sejak berabad-abad yang laulu. Tetapi, Islam tiba dengan damai karena ajarannya mampu memberikan aspek dasar kehidupan masyarakatnya. Islam bisa beradaptasi dengan keadaan masyarakat yang mempunyai aneka ragam kebudayaana dan kebiasaan dengan memakai beberapa metode pendekatan sebagai pengaruhnya warga daerah menerima dengan terbuka maupun dengan jalan damai.

Dengan mengambil pembahasan pada beberapa penjelasan diatas maka 
dapat diberikan pandangan Islam terhadap tradisi Songkabala bisa dikaitkan sebagai berikut:

1. Pandangan Islam dari hal maupun segi pelaksanaannya tradisi ritual Songkabala dalam membacakan doa dalam rangka meminta keselamatan. Berarti tidak bertentangan dengan ajaran Islam atau kepercayaan Islam. Sebab, dimana saat dilakukannya doadoa tersebut. Masyarakat hanya meminta perlindunagn kepada Allah SWT agar terhindar dari berbagi musibah, bencana, juga malapetaka yang akan tiba menimpa masyarakat itu sendiri.

2. Pandangan Islam yang muncul dari hal hubungan masyarakat atau berdasarkan nilai ukhuwah yang sering kita pelajari, dalam hal tradisi ritual Songkabala, yaitu Islam tidak melarangnya justru menganjurkan untuk saling menyambung dan menjaga tali silaturahim dengan sesama umat manusia lainnya tanpa melihat kepercayaan, ras, suku, maupun warna kulitnya.

3. Pandangan Islam terhadap tradisi Songkabala dalam hal makanan atau sesajian yang dipersiapkan buat pelaksanaannya demi terselenggaranya ritual dengan baik. Yaitu, Islam tidak mengajarkan atau mensyaratkan untuk menyiapakan makanan tertentu atau yang wajib. Islam hanya menganjurkan buat mengirim doa adan membacakan doa untuk meminta arahan ataupun meminta keselamatan kepada Allah SWT. Apabila hanya untuk membuat makanan dengan tujuan dalm rangka dimakan bersama-sama sesudah ritual selesai itu diperbolehkan.

Pelaksanaan ritual tradisi Songkabala tidak dapat dipisahkan dari nilai-nilai luhur sebagaimana dimiliki oleh uatu budaya pada umumnya seperti yang telah dijelaskan sebelumnya. Tradisi ini memilki nilai yang berdasarkan pandangan Islam wajib dijaga dan dilestarikan. Nilai itu merupakan nilai ukhwuah dalam Islam yang terkait pada pelaksanaan tradisi Songkabala. yang mana masyarkatnya saling membantu menyiapkan makanan, berkumpul bersama, berdoa bersama, serta makan bersama. Guna membentuk keakraban diantara para masyarakat yang ikut pada tradisi tersebut. Islam mengajarkan untuk saling menghargai, menghormati, dan menjaga, satu dengan individu lainnya. Oleh dengan masyarakat yang masih tetap melestarikan dan menjaga tradisi kebudayaan ini, juga memilki tujuan guna menghargai tradisi nenek moyang atau leluhur dalam menjaganya dan merawatnya. Kebudayaan lokal yang tradisional bukan berarti harus menggantikan dengan kebudayaan baru. Namun perlu diketahui bahwa disesuikan dengan waktu sekarang ini dengan aturan yang berlaku, selama dari mereka tidak menyalahi atau melanggar aturan kebudayaan yang melanggar ajaran Islam itu harus tetap dilestarikan.

\section{Kesimpulan}

Tradisi Songkabala dalam bahasa Makassar dipahami oleh masyarakat Desa Minasa Upa, Kecamatan Bontoa, Kabupaten Maros. yang mengandung makna atau arti pada bahasa Indonesia tolak bala berupa bencana atau bisa juga diartikan meminta keselamatan kepada tuhan yang maha esa. Songkabala merupakan ritual yang masih dilaksanakan untuk menolak musibah, bencana, juga malapetaka yang akan datang untuk menimpa masyarakat. Tradisi tersebut dilakukan apabila ada penyampaian dari tokoh agama atau yang biasa disebut oleh masyarakat ialah Imam kampung dan Imam Desa bahwa kita akan melakukan tradisi songkabala. Bertempat pada mesjid dengan membawa makanan tertentu pada waktu 
menjelang maghrib serta dilaksanakan selesainya maghrib, poin utama dari tradisi ini ialah terletak di waktu pelaksanaannya dimana terlihat dengan jelas bahwa tradisi ini sangat erat kaitannya dengan kepercayaan. Dimana terdapat unsur doa kepada pencipta alam semesta atau kepada tuhan yang maha esa, yang dipimpin pribadi oleh tokoh agama.

Sebelum melaksanakan tradisi Songkabala maka terlebih dahulu wajib menyiapkan alat yang dibutuhkan dan makanan yang diwajibkan harus terdapat pada tradisi tersebut. Dimana alat dam sajian makanan tersebut mempunyai makna yang mendalam bagi masyarakat Islam Desa Minasa Upa. sementara warga yang melaksanakan tradisi Songkabala mengatakan bahwa ritual tersebut tidak bertentangan dengan Islam sebab mereka memanjatkan doa kepada Allah SWT serta makanan yang dibawa ke mesjid niat buat makan bersama warga yang ikut serta dalam tradisi tersebut. Islam menjadi agama yang memiliki ajaran yang universal atau umum dimana mengandung nilai-nilai budaya serta mengatur segala kegiatan manusia baik menyangkut hubungan manusia dengan manusia lainnya, manusia dengan mahluk hidup lain seperti binatang, tumbuhan, serta hubungan manusia dengan lingkungan alam sekitarnya, dan hubungan manusia dengan yang maha kuasa.

Masyarakat Islam di Desa Minasa Upa melaksanakan tradisi sebagai bentuk memohon keselamatan kepada pencipta alam semesta agar dihindarkan dari segala bencana, musibah, maupun malapetaka. Dalam pelaksanaan tradisi songkabala, ada beberapa nilai budaya juga terungkap di dalamnya, seperti nilai gotong royong, nilai agama/religi, nilai sosialisasi, nilai musyawarah, nilai pengetahuan lokal, dan nilai keindahan. Adapun fungsi yang bisa didapatkan dari tradisi songkabala yaitu, bisa mendekatkan diri kepada Tuhan, sebagai bentuk pelestaraian kearifan lokal, dan mencerminkan hubungan kekeluargaan dalam masyarakat. Adapun beberapa saran yang berdasarkan pada tradisi tersebut. Ialah, Kepada masyarakat Desa Minasa Upa agar tetap menjaga kelestarian tradisi songkabala karena dalam pelaksanaanya mengandung makna atau arti yang sangat bermanfaat.

\section{Bibliografi}

Hermawan, S. P. I. (2019). Studi Islam Nusantara. YAYASAN HJ. KARTINI KUDUS.Google Scholar

Jeumpa, N. (2018). Nilai-Nilai Agama Islam. Pedagogik: Jurnal Ilmiah Pendidikan Dan Pembelajaran Fakultas Tarbiyah Universitas Muhammadiyah Aceh, 4(2), 101-112. Google Scholar

Kaukab, E. (2017). Kompetensi Lintas Budaya Dalam Internasionalisasi Umkm Di Indonesia Sebuah Agenda Penelitian. Fokus Bisnis: Media Pengkajian Manajemen Dan Akuntansi, 16(01), 4050. Google Scholar

Koentjaraningrat, K. (1985). Mentalitas dan Pembangunan. Jakarta: Gramedia. Google Scholar

Pals, D. L. (1996). Seven theories of religion. IRCiSoD. Google Scholar

Puspitasari, D. R. (2014). Perwujudan nilainilai budaya dalam Batu Flowers Festival di Kota Batu. Universitas Negeri Malang. Google Scholar

Sabri, M. (2014). Tasbih dan Bakul: Studi Antropologi Agama tentang Songkabala. SOSIORELIGIUS, 1(2). Google Scholar

Saputra, I. K. E., Sutrawan, G. Y., PF, K. A. P. D., \& Sugita, I. W. (2019). Literasi Humanistik Dalam Tradisi Ngaroangin. Prosiding Nasional, 135-140. Google Scholar

Soendari, T. (2012). Metode Penelitian Deskriptif. Bandung, UPI. Stuss, 
Songkabala: Tradisi Menolak Bencana Masyarakat Islam Desa Minasa Upa Kabupaten Maros

Sulawesi Selatan

Magdalena \& Herdan, Agnieszka, 17. Tanzeh (ed.); 1st ed.). Akademia Google Scholar

Pustaka. Google Scholar

Suyitno. (2018). Penelitian kualitatif (A.

Copyright holder :

Irman (2021).

First publication right :

Action Research Literate

This article is licensed under:

(c) (†) (อ) 